\title{
Higher yielding varieties of common buckwheat (Fagopyrum escu- lentum Moench) with determinate growth habit (single mutation det) manifest higher photosynthesis rate at stage of grain filling
}

\author{
Alexandr V. AMELIN ${ }^{1}$, Aleksey N. FESENKO ${ }^{2}$, Evgeniy I. CHEKALIN ${ }^{1}$, Ivan N. FESENKO ${ }^{2,3}$, Valeriy V. \\ ZAIKIN $^{1}$
}

Received October 28, 2019; accepted January 4, 2020.

Delo je prispelo 28. oktobra 2019, sprejeto 4. januarja 2020.

Higher yielding varieties of common buckwheat (Fagopyrum esculentum Moench) with determinate growth habit (single mutation det) manifest higher photosynthesis rate at stage of grain filling

Abstract: Comparison of common buckwheat varieties with determinate vs. indeterminate growth habit reveals no differences in leaf photosynthesis rate at stage before flowering. However, at stage of seed filling the difference was significant. Maximal difference was 20 days after early flowering, i.e in period of most intensive seed formation. These results show that determinate varieties have higher sink strength providing by developing seeds. It is correlated with higher yield ability of such varieties. Probably, growth limitation resulting from det-mutation leads to some shifts in system of sink priorities of buckwheat plant and allows initiate the development of additional seeds. One more possible cause of alteration of the physiological parameters in determinate varieties is some optimization of plant structure: in terms of physiology the determinate buckwheat is a plant which is more similar to cereals than indeterminate buckwheat. However, underlying physiological changes accompanying the transition from indeterminate toward determinate growth in buckwheat remain almost unknown. Assumption about strong effect of det-mutation per se on photosynthesis rate was not supported in our work. Alternative assumption about accumulation of additional genes enhancing the sink ability suggests opportunities for additional progress in the selection work using tools evaluating photosynthesis intensity at stage of grain filling.

Key words: Fagopyrum esculentum; buckwheat; photosynthesis rate; sink strength; growth habit
Bolj donosne sorte navadne ajde (Fagopyrum esculentum Moench) $\mathrm{z}$ determinantno rastjo (enojna det mutacija) imajo večjo fotosintezo $\mathrm{v}$ fazi polnjenja zrnja

Izvleček: Primerjava sort navadne ajde $\mathrm{z}$ determinantno in nedeterminatno rastjo ne kaže razlik $\mathrm{v}$ fotosintezi listov $\mathrm{v}$ fazi pred cvetenjem, vendar je razlika $v$ fazi polnjenja zrnja značilna. Največja razlika je bila20 dni po začetku cvetenja, to je $\mathrm{v}$ fazi najbolj intezivnega oblikovanja semen. Ti izsledki kažejo, da imajo determinantne sorte večjo moč ponora, ki jo dajejo razvijajoča se semena. To je povezano tudi s sposobnostjo večjega pridelka teh sort. Verjetno je omejitev rasti posledica det-mutacije, kar vodi v nekatere premike $\mathrm{v}$ siste$\mathrm{mu}$ prioritet ponora $\mathrm{v}$ rastlinah ajde in, kar vzpodbudi razvoj dodatnih semen. Nadaljni možni vzrok v spremembi fizioloških parametrov determinatnih sort je v optimizaciji zgradbe rastline, determinatna ajda je $\mathrm{v}$ fiziološkem pogledu bolj podobna žitom kot pa nedeterminatni ajdi. Kljub vsemu, pa ostajajo fiziološke spremembe, ki spremljajo prehod od nedeterminantne $\mathrm{k}$ determinatni rasti skoraj popolnoma neznane. Domneva o močnemu činku det-mutacije per se na fotosintezo v našem delu ni bila potrjena. Alternativna domneva o kopičenju dodatnih genov, ki pospešujejo sposobnost ponora daje priložnosti za nadaljni napredek pri selekcijskem delu $\mathrm{z}$ uporabo ovrednotenja jakosti fotosinteze kot orodja $\mathrm{v}$ fazi polnjenja zrnja.

Ključne besede: Fagopyrum esculentum; navadna ajda; velikost fotosinteze; moč ponora; rastna oblika

1 Orel State Agrarian University, 302019, Generala Rodina 69, Orel, Russia

2 Federal Scientific Center of Legumes and Groats Crops, 302502, p/o Streletskoe, Orel, Russia

3 Corresponding author, e-mail: ivanfesenko@rambler.ru 


\section{INTRODUCTION}

Fagopyrum esculentum Moench (common buckwheat) is a species cultivated as groats or grain crop in many countries, mainly in Russia and China (Wang \& Campbell, 2004; Fesenko et al., 2016). During a last half of century, crop evolution of common buckwheat have resulted the increasing of the species grain productivity. Physiological basis of the result is mainly unknown. Probably, it was associated with correction of sourcesink relationships.

In Russia, breeding of this crop on scientific basis was started in 1900s on Shatilov's Experimental Station (Orel region, Russia). First Russian commercial variety, Bogatyr, was bred by selection of heavier (i.e. larger and better filled) fraction of grain from cultivated local buckwheat. Beginning from 1960s buckwheat breeding in Russia is based on application of several morphological mutations (Fesenko, 1983; Fesenko et al., 2006). Agricultural practice has chosen mainly determinate varieties based on a mutation $d(d e t)$ (Fesenko, 1968; Ohnishi, 1990) that limits the generative development of shoots by 3-5 inflorescences without possibility for development of any additional ones (Fesenko, 1983; Fesenko et al., 2009)(Fig. 1). First variety of this type was registered in 1985 . Since the beginning of $21^{\text {st }}$ century the share of the determinate varieties in the buckwheat sowing area in Russia was increased from $8.2 \%$ to 56.2 $\%$, which led to an increase in average buckwheat yield by 1.5 times (FAO, 2014). Breeding and research work with determinate type buckwheat was conducted also in Slovenia (Bohanec \& Kreft, 1981; Luthar et al., 1986; Kreft, 1989), Serbia (Nešković et al., 1990) and Japan (Kasajima et al., 2016).

The steady increase in productivity of determinate varieties compared to traditional ones implies, among others, changes in their physiology, which probably include correcting some processes associated with regulation of photosynthesis. Although the results of experiments evaluating correlation between photosynthesis rate and plant productivity are not always unambiguous (Peng et al., 1991; Long et al., 2006; Driever et al., 2014), the intensification of the assimilate synthesis looks as one of major factors in plant productivity growth.

Since changes in the intensity of photosynthesis are one of the supposed reasons for a higher grain productivity of buckwheat with determinate growth, we compared the common buckwheat varieties of indeterminate, i.e. traditional, and determinate types on seasonal dynamics of the photosynthesis rate. Also, we evaluated the influence of det-mutation itself on photosynthesis rate in buckwheat. The aim of this article was to describe results of this work and to discuss it.

\section{MATERIAL AND METHODS}

\subsection{PLANT MATERIAL}

Two local cultivars from Orel region represented by accessions k-406 and k-1709 from collection of Vavilov's Institute of Plant Industry, St.-Petersburg; three varieties of traditional type with indeterminate growth habit (genotype DET/DET) Bogatyr (registered in 1938), Kalininskaya (1954) and Shatilovskaya 5 (1967); four varieties with determinate growth (genotype det/det) Demetra (1995), Dozhdik (1998), Dikul (1999) and Devyatka (2004). All the varieties are similar in characteristics of vegetation period and manifest similar time of flowering beginning. $\mathrm{F}_{2}$ hybrids 'Dikul

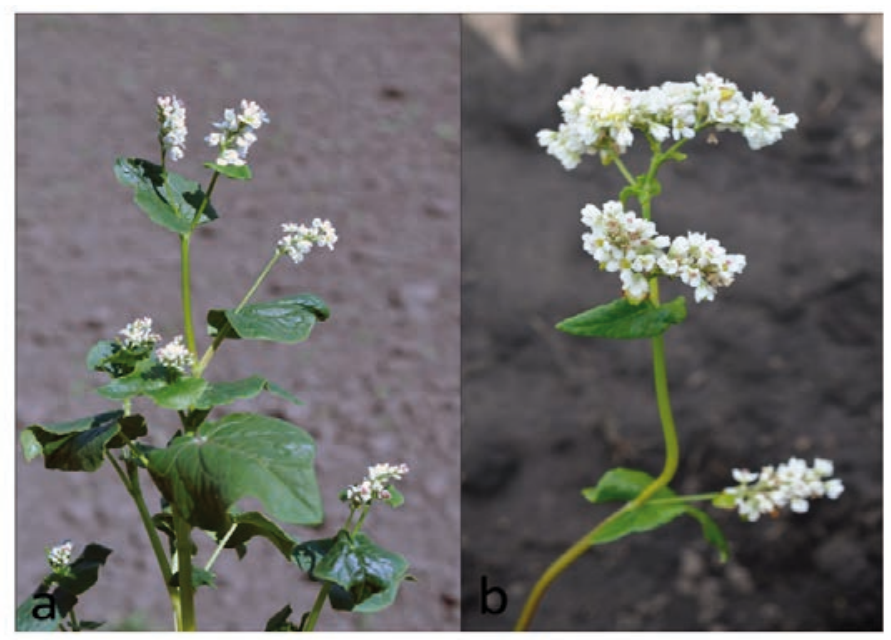

Figure 1: Shoots of a) determinate and b) indeterminate buckwheat shoots 
Table 1: Some essential dates of the experiment

\begin{tabular}{lllll}
\hline Year & Sowing date & Date of seedlings appearance & Varieties groups & ${ }^{*}$ Dates of early flowering \\
\hline 2013 & May 23 & May 29 & Indeterminate & June 19-20 \\
& & & Determinate & June 19-22 \\
2014 & May 21 & May 27 & Indeterminate & June 15-19 \\
& & & Determinate & June 18-20 \\
2015 & May 29 & June 4 & Indeterminate & June 28 \\
& & & Determinate & June 28-29 \\
\hline
\end{tabular}

* $10-15 \%$ of plants have any opened flowers

Table 2: Weather conditions in days when photosynthesis rate was measured

\begin{tabular}{|c|c|c|c|c|c|}
\hline \multirow[b]{2}{*}{ Year } & \multirow[b]{2}{*}{ Date } & \multicolumn{2}{|c|}{ Air temperature, ${ }^{\circ} \mathrm{C}$} & \multicolumn{2}{|c|}{ Air humidity, \% } \\
\hline & & average & $\max$ & average & $\min$ \\
\hline \multirow[t]{4}{*}{2013} & June 13 & 19.5 & 24.4 & 61 & 41 \\
\hline & June 26 & 21.8 & 30.9 & 81 & 49 \\
\hline & July 6 & 23.9 & 31.1 & 64 & 34 \\
\hline & July 16 & 17.1 & 21.6 & 90 & 73 \\
\hline \multirow[t]{3}{*}{2014} & July 3 & 21.8 & 26.5 & 39 & 22 \\
\hline & July 14 & 13.6 & 18.0 & 81 & 61 \\
\hline & July 24 & 13.6 & 19.2 & 74 & 49 \\
\hline \multirow[t]{4}{*}{2015} & June 20 & 15.6 & 18.0 & 93 & 90 \\
\hline & July 6 & 21.2 & 27.1 & 60 & 42 \\
\hline & July 16 & 17.4 & 24.2 & 76 & 43 \\
\hline & July 26 & 26.3 & 33.8 & 57 & 37 \\
\hline 2018 & July 13 & 22.1 & 28.8 & 69 & 39 \\
\hline
\end{tabular}

$\times$ Bogatyr' were used to evaluate the influence of detmutation itself on photosynthesis intensity.

\subsection{EXPERIMENTAL DESIGN}

The experiment was conducted in 2013-2015 in crop rotation of buckwheat breeding laboratory of the All-Russia Research Institute of Grain Legumes and Groats Crops, Orel, Russia. A plot area was $10 \mathrm{~m}^{2}$. The plots locations were random, with fourfold replication. Sowing rate was 300 seeds per square meter. Dates of sowing and early flowering are presented in Table 1.

The photosynthesis intensity was evaluated on intact plants in real-time regime with a portable gas analyzer Li-COR - 6400 using the original methodology of the company $\mathrm{Li}-\mathrm{COR}$. The evaluations were conducted three times in 2014 and four times in both 2013 and 2015 at different developmental stages (see Results). Fifteen plants of every determinate variety and twelve plants of every indeterminate one were analyzed every time of the experiment (60 plants of every type in sum). The measurements were made in order "indeterminate - determinate - indeterminate - etc" with alteration every five plants.

Yield data were obtained by weighting of the grain yield from each plot. All these parameters were used to compare the two groups of varieties, i.e. indeterminate (traditional) vs. determinate. Significance of the differences between the groups was evaluated using $t$ statistics.

\subsection{WEATHER CONDITIONS}

Weather conditions deviate during experiments, but in permissible range (Table 2). In addition, gas exchange was evaluated in morning time, 9AM - 11AM, when conditions were maximally suitable. They did not notably influence the results of gas exchange evaluation. For example, photosynthesis rate was not decreased in 2014 July 14, the coldest day of the work, in comparison 
with results at this developmental stage in two other years.

\section{RESULTS}

\subsection{GRAIN PRODUCTIVITY OF VARIETIES IN THE EXPERIMENT}

In this experiment the determinate varieties manifest higher grain productivity than the indeterminate varieties, on average; the difference was significant in all years of the study (Table 3 ).

\subsection{PHOTOSYNTHESIS RATE AT DIFFERENT DEVELOPMENTAL STAGES}

At stage before flowering the photosynthesis rate was measured only in 2013 and 2015. In a season scale, in 2013 this stage values of photosynthesis rate were maximal, but in 2015 - minimal. Comparison between 2013 and 2015 reveals at least twice difference (Table 4), but comparison between indeterminate and determinate varieties in every year reveals no any differences.

During period of flowering, i.e. 10, 20 and 30 days followed to early flowering, the measuring of photosynthesis rate was conducted in 2013, 2014 and 2015. Determinate varieties manifest significantly higher mean values of $\mathrm{CO}_{2}$ exchange in all cases with an exception of 10 days after early flowering in 2014 (Table 4). In all years of the experiment the maximal differences between determinate and indeterminate varieties were at stage of 20 days after early flowering.

Maximal values of photosynthesis rate among determinate and indeterminate varieties sometimes were almost identical, and sometimes were even higher for indeterminants. Therefore, really, the possible maximal $\mathrm{CO}_{2}$ exchange at level of individual plant of determinate varieties is not always higher, but $\mathrm{CO}_{2}$ exchange at population level is always sufficiently more consistent

Table 3: Grain yield $\left(\mathrm{t} \mathrm{ha}^{-1}\right)$ of varieties with indeterminate and determinate growth habits

\begin{tabular}{lllll}
\hline Year & Varieties group & $\mathrm{X} \pm \mathrm{m}$ & $\mathrm{t}$ & $\mathrm{P}$ \\
\hline 2013 & Indeterminate & $1.02 \pm 0.12$ & & \\
& Determinate & $1.38 \pm 0.11$ & 2.21 & 0.05 \\
2014 & Indeterminate & $1.49 \pm 0.06$ & & \\
& Determinate & $1.97 \pm 0.07$ & 5.21 & 0.001 \\
2015 & Indeterminate & $1.25 \pm 0.09$ & & \\
& Determinate & $1.52 \pm 0.08$ & 2.24 & 0.05 \\
\hline
\end{tabular}

at stage of seed filling. It correlates with the sufficiently higher and more consistent grain productivity of determinate varieties in Russia.

\subsection{THE DET-MUTATION PER SE DOES NOT AF- FECT THE PHOTOSYNTHESIS RATE}

The differences between varieties with indeterminate and determinate growth habits in the photosynthesis rate at stage of grain filling may be due to either the effect of the det-allele per se or the accumulation of additional genes affecting the intensity of gas exchange. We analyzed $\mathrm{F}_{2}$ hybrids between indeterminate (Bogatyr) and determinate (Dikul) varieties. As expected, all $\mathrm{F}_{1}$ hybrids were indeterminate; $\mathrm{F}_{2}$ segregation was Mendelian, 182 indeterminate : 67 determinate $\left(\chi^{2}=0.48 ; p\right.$ $=0.49$ ). For the test 55 plants of each type were selected and labeled. Measurements were made alternately: one determinate plant, one indeterminate plant etc. The experiment shown no differences in photosynthesis rate between the indeterminate and determinate groups of $\mathrm{F}_{2}$ hybrids: photosynthesis rate was $10.89 \pm 0.51$ with range $1.32-18.22$ for indeterminate sample and 10.07 \pm 0.57 with range $1.00-20.12$ for determinate sample from $\mathrm{F}_{2}$ population $(\mathrm{t}=1.07 ; p>0.1)$. Therefore, the advantages of determinant varieties in photosynthesis rate are not directly conditioned by det-allele. Obviously, some other genes were accumulated which increase the photosynthesis rate at stage of grain filling. This indicates the possibility of selection for the intensity of photosynthesis.

\section{DISCUSSION}

Photosynthesis rate is regulated by sink strength (assimilate demand) and source strength (assimilate supply) (King et al., 1967; Marcelis et al., 2004; Wubs et al., 2009; Borrill et al., 2015; Zhang et al., 2015; White et al., 2016). Obviously, there are limitations for the photosynthesis intensity, which are various between crops. So, maximal values of $\mathrm{CO}_{2}$ assimilation was $42.5 \mu \mathrm{mol} \mathrm{m}{ }^{-2}$ $\mathrm{s}^{-1}$ for sorghum (Salas-Fernandes et al., 2015) and 30-33 $\mu \mathrm{mol} \mathrm{m} \mathrm{m}^{-2} \mathrm{~s}^{-1}$ for a high-yielding indica cultivar of rice (Adachi et al., 2014). Sometimes, photosynthesis rate is restricted by $\mathrm{CO}_{2}$ concentration in air: several studies on rice revealed polymorphism for reaction on increasing of $\mathrm{CO}_{2}$ concentration in air that was interpreted as differences in sink ability of filling grain between different varieties (Chen et al., 2014; Zhu et al., 2014).

However, photosynthetic apparatus usually does not work at full capacity. So, reported maximum indi- 
Table 4: Leaf photosynthesis rate $\left(\mu \mathrm{mol} \mathrm{m} \mathrm{m}^{-2} \mathrm{~s}^{-1}\right.$ of buckwheat plants at different stage of their life cycle in field conditions

\begin{tabular}{|c|c|c|c|c|c|c|}
\hline \multirow[b]{2}{*}{ Year } & \multirow[b]{2}{*}{ Developmental stage } & \multirow[b]{2}{*}{ Date } & \multirow{2}{*}{$\begin{array}{l}\text { Indeterminate varieties } \\
\mathrm{X} \pm \mathrm{m} \text { (range) }\end{array}$} & \multirow{2}{*}{$\begin{array}{l}\text { Determinate varieties } \\
\mathrm{X} \pm \mathrm{m} \text { (range) }\end{array}$} & \multirow[t]{2}{*}{$\mathrm{t}$} & \multirow[t]{2}{*}{$\mathrm{P}$} \\
\hline & & & & & & \\
\hline \multirow[t]{4}{*}{2013} & Before flowering & June 13 & $\begin{array}{l}14.04 \pm 0.75 \\
(8.54-21.85)\end{array}$ & $\begin{array}{l}14.78 \pm 1.05 \\
(8.45-21.97)\end{array}$ & 0.57 & - \\
\hline & $\begin{array}{l}10 \text { days after early } \\
\text { flowering }\end{array}$ & June 26 & $\begin{array}{l}9.59 \pm 0.62 \\
(4.14-17.30)\end{array}$ & $\begin{array}{l}11.84 \pm 0.64 \\
(5.77-16.25)\end{array}$ & 2.53 & 0.02 \\
\hline & $\begin{array}{l}20 \text { days after early } \\
\text { flowering }\end{array}$ & July 6 & $\begin{array}{l}9.03 \pm 0.80 \\
(4.25-15.69)\end{array}$ & $\begin{array}{l}14.68 \pm 0.51 \\
(10.75-18.60)\end{array}$ & 5.96 & 0.001 \\
\hline & $\begin{array}{l}30 \text { days after early } \\
\text { flowering }\end{array}$ & July 16 & $\begin{array}{l}9.54 \pm 0.47 \\
(5.32-12.98)\end{array}$ & $\begin{array}{l}12.08 \pm 0.43 \\
(8.43-15.47)\end{array}$ & 3.96 & 0.001 \\
\hline \multirow[t]{3}{*}{2014} & $\begin{array}{l}10 \text { days after early } \\
\text { flowering }\end{array}$ & July 3 & $\begin{array}{l}10.24 \pm 0.60 \\
(6.23-17.30)\end{array}$ & $\begin{array}{l}11.04 \pm 0.51 \\
(7.98-14.67)\end{array}$ & 1.02 & - \\
\hline & $\begin{array}{l}20 \text { days after efflores- } \\
\text { cence }\end{array}$ & July 14 & $\begin{array}{l}11.76 \pm 0.62 \\
(5.77-17.62)\end{array}$ & $\begin{array}{l}13.56 \pm 0.57 \\
(8.81-17.54)\end{array}$ & 2.14 & 0.05 \\
\hline & $\begin{array}{l}30 \text { days after early } \\
\text { flowering }\end{array}$ & July 24 & $\begin{array}{l}8.55 \pm 0.27 \\
(6.05-11.99)\end{array}$ & $\begin{array}{l}9.63 \pm 0.46 \\
(6.44-14.00)\end{array}$ & 2.02 & 0.05 \\
\hline \multirow[t]{4}{*}{2015} & Before flowering & June 20 & $\begin{array}{l}6.50 \pm 0.09 \\
(5.87-6.96)\end{array}$ & $\begin{array}{l}6.24 \pm 0.13 \\
(5.58-6.78)\end{array}$ & 1.64 & - \\
\hline & $\begin{array}{l}10 \text { days after early } \\
\text { flowering }\end{array}$ & July 6 & $\begin{array}{l}11.44 \pm 0.19 \\
(10.48-12.96)\end{array}$ & $\begin{array}{l}12.57 \pm 0.27 \\
(11.21-14.28)\end{array}$ & 3.42 & 0.001 \\
\hline & $\begin{array}{l}20 \text { days after early } \\
\text { flowering }\end{array}$ & July 16 & $\begin{array}{l}12.19 \pm 0.18 \\
(11.14-13.10)\end{array}$ & $\begin{array}{l}14.07 \pm 0.17 \\
(13.33-14.70)\end{array}$ & 7.59 & 0.001 \\
\hline & $\begin{array}{l}30 \text { days after early } \\
\text { flowering }\end{array}$ & July 26 & $\begin{array}{l}8.27 \pm 0.19 \\
(6.97-9.30)\end{array}$ & $\begin{array}{l}9.38 \pm 0.15 \\
(8.32-10.17)\end{array}$ & 4.59 & 0.001 \\
\hline
\end{tabular}

vidual leaf net $\mathrm{CO}_{2}$ assimilation rates for $V$. vinifera $\mathrm{L}$. and other Vitis species approach $20 \mu \mathrm{mol} \mathrm{m}{ }^{-2} \mathrm{~s}^{-1}$ (Roper \& Williams, 1989; Gamon \& Pearcy, 1990). But more commonly reported maximum rates fall in the range of 8 to $13 \mu \mathrm{mol} \mathrm{CO} \mathrm{m}^{-2} \mathrm{~s}^{-1}$ (Downton et al., 1987; Correia et al., 1990). On Eucalyptus globulus Labill. excision of several leaves causes increased photosynthesis in the remained leaves (Eyles et al., 2013). In addition, the increased assimilate demand also enhances photosynthesis (Aranjuelo et al., 2013). Finally, total sink strength can be increased as result of interactions with other organisms: for example, soybean plants inoculated with two different strains of Bradyrhizobium japonicum (Kirchner,1896) Jordan, 1982 had 14-31 \% higher rates of photosynthesis than $\mathrm{N}$-fertilized plants (Kaschuk et al., 2012).

Different groups of buckwheat varieties were not different in both sink and source strength at stage of vegetative development. However, at stage of seed filling the significant differences in photosynthesis rate were revealed between varieties with determinate vs. indeterminate growth habits. At present time the varieties with determinate growth habit cover more than a half of sowing area under buckwheat in Russia. Earlier, the higher productivity of such varieties was interpret- ed only in terms of shift in balance between competitive sinks, i.e. vegetative growth and seed development. Our work elucidates that grain filling in buckwheat is limited by itself sink capacity rather than source capacity of leaves and competitive interactions with other growing organs.

All buckwheat varieties produce redundant number of flowers. Obviously, not all of the flowers produce seeds. It was discussed that there is often a hierarchy among sinks (Wardlaw, 1990), i.e. some organs have priority and suffer less from a reduction in assimilate supply than other organs. Such hierarchy usually is resulted from evolution of certain strategy of a species adaptation (Wardlaw, 1990). Since main adaptive property of common buckwheat is ability to continuous intensive growth, primary sinks in buckwheat plant are shoot meristems; seed production is only secondary sink (Fesenko, 1983). It explains the very little increasing of buckwheat seed productivity due to selection of most vigorous and productive plants. Progeny of such plants also had vigorous growth (maybe more vigorous than parental population), but competition between plants in the canopy was also very strong, and seed production was poor: only few plants produce sufficient num- 
ber of seeds, and productivity of whole canopy remains low (Fesenko et al., 2006).

Determinate varieties manifest higher and more consistent yield obviously due to set several additional seeds per plant in comparison to indeterminate varieties. Setting the additional seeds on determinate plants could be explained by essentially reduced competition from vegetative growth at time of seed formation in comparison to indeterminate ones. However, this hypothesis does not explain why seed filling together with indeterminate growth in varieties of traditional type drive less sink strength than seed filling together with reduced vegetative growth in varieties of determinate type. Besides, it does not answer a question, why indeterminate varieties do not set additionally seeds with possible following growth of photosynthesis rate?

Probably, growth limitation resulting from detmutation leads to some shifts in the priorities and allows initiate the development of additional seeds. One more possible base of the alteration of physiological and grain yield parameters in determinate varieties is some optimization of plant structure: determinate buckwheat is a plant, which is more similar with cereals than indeterminate buckwheat (det-mutation is a first step of buckwheat to became "cereal" in terms of physiology). However, underlying physiological changes accompanying the transition from indeterminate toward determinate growth in buckwheat remain almost unknown.

Attempting to determine any genes influencing photosynthesis rate led to discovering QTLs affecting, for example, chlorophyll content, stomatal resistance, transpiration rate (Teng et al., 2004; Wang et al., 2015), mesophyll conductance, and root surface area determining hydraulic conductance (Adachi et al., 2014). A mutation of rice erect panicle 3 (ep3) decreases photosynthesis due to reducing stomatal conductance (Yu et al., 2015).

Assumption about strong effect on photosynthesis rate of det-mutation per se was not supported in our work. Possible alternative explanation for higher photosynthesis rate together with higher seed productivity of the determinate varieties is accumulation of some additional genes enhancing the sink ability of filling seeds. The mechanisms of functioning of these genes are currently unknown. However, such assumption suggests opportunities for additional progress in the selection work using tools evaluating photosynthesis intensity at stage of grain filling.

\section{CONCLUSION}

The present study revealed the buckwheat varieties with determinate growth habit (a mutation det) manifested higher photosynthesis rate at stage of grain filling compared to varieties with indeterminate growth habit. The mutation det itself is not determining the difference. Perhaps, some other genes increasing photosynthesis rate at stage of grain filling, i.e. sink strength of developing seeds pool, were accumulated in determinate varieties. Probably, there are some possibilities to continue the selection for photosynthesis rate in buckwheat.

\section{REFERENCES}

Adachi, S., Baptista L.Z., Sueyoshi T., Murata K., Yamamoto T., Ebitani T., .Hirasawa T. (2014). Introgression of two chromosome regions for leaf photosynthesis from an indica rice into the genetic background of a japonica rice. Journal of Experimental Botany, 65, 2049-2056. https://doi: 10.1093/jxb/eru047

Aranjuelo, I., Sanz-Saez, A., Jauregui, I., Irigoyen, J.J., Araus, J.L., Sanchez-Diaz, M., Erice, G. (2013). Harvest index, a parameter conditioning responsiveness of wheat plants to elevated $\mathrm{CO}_{2}$. Journal of Experimental Botany, 64, 18791892. https://doi:10.1093/jxb/ert081

Bohanec, B., Kreft, I. (1981). Appearance of genetic factor for determinant habit in population of grey buckwheat in Slovenia. Zbornik Biotehniške Fakultete UL, Agricultural issue, 37, 69-72.

Borrill, P., Fahy, B., Smith, A.M., Uauy, C. (2015). Wheat grain filling is limited by grain filling capacity rather than the duration of flag leaf photosynthesis: a case study using NAM RNAi plants. PLoS ONE, 10(8), e0134947. https:// doi:10.1371/journal.pone.0134947

Chen, Ch.P., Sakai, H., Tokida, T., Usui, Y., Nakamura, H., Hasegawa, T. (2014). Do the rich always become richer? Characterizing the leaf physiological response of the high-yielding rice cultivar Takanari to free-air $\mathrm{CO}_{2}$ enrichment. Plant \& Cell Physiology, 55(2), 381-391. https:// doi:10.1093/pcp/pcu009

Correia, M.J., Chaves, M.M.C., Pereira, J.S. (1990). Afternoon depression in photosynthesis in grapevine leaves: evidence for a high light stress effect. Journal of Experimental Botany, 41, 417-426.

Downton, W.J.S., Grant, W.J.R., Loveys, B.R. (1987). Diurnal changes in the photosynthesis of field-grown grapevines. New Phytologist, 105, 71-80. https://doi: 10.1111/j.14698137.1987.tb00111.x

Driever, S.M., Lawson, T., Andralojc, P.J., Raines, C.A., Parry, M.A.J. (2014).Natural variation in photosynthetic capacity, growth, and yield in 64 field-grown wheat genotypes. Journal of Experimental Botany, 65, 4959-4973. https:// doi:10.1093/jxb/eru253

Eyles, A., Pinkard, E.A., Davies, N.W., Corkrey, R., Churchill, K., O’Grady, A.P., Sands, P., Mohammed, C. (2013). Wholeplant- versus leaf-level regulation of photosynthetic responses after partial defoliation in Eucalyptus globulus- 
saplings. Journal of Experimental Botany, 64, 1625-1636. https://doi:10.1093/jxb/ert017

FAO. (2014). FAOSTAT database. Retrieved from http://www. fao.org/faostat/en/\#home

Fesenko, A.N., Fesenko, N.N., Romanova, O.I., Fesenko, I.N. (2016). Crop Evolution of Buckwheat in Eastern Europe: Microevolutionary trends in the secondary center of buckwheat genetic diversity. In: M. Zhou, I. Kreft, S.-H. Woo, N. Chrungoo, G. Wieslander (Eds.) Molecular Breeding and Nutritional Aspects of Buckwheat (pp. 99-107). Elsevier.

Fesenko, I.N., Fesenko, A.N., Biryukova, O.V., Shipulin, O.A. (2009). Genes regulating inflorescences number in buckwheat with a determinate growth habit (homozygote at the recessive allele det). Fagopyrum, 26, 21-24.

Fesenko, N.V. (1968). A genetic factor responsible for the determinant type of plants in buckwheat. Genetika, 4, 165-166. (in Russian)

Fesenko, N.V. (1983). Breeding and seed farming of buckwheat. Moscow: Kolos. (in Russian)

Fesenko, N.V., Fesenko, N.N., Romanova, O.I., Alexeeva, E.S., Suvorova, G.N. (2006). Buckwheat (Theoretical basis of plant breeding). St.-Petersburg: Vavilov's Institute of Plant Industry. (in Russian)

Gamon, J.A., Pearcy, R.W. (1990). Photoinhibition in Vitiscalifornica:interactive effects of sunlight, temperature and water status. Plant Cell \& Environment, 13, 267-275. https://doi:10.1111/j.1365-3040.1990.tb01311.x

Kasajima, S., Namiki, N., Morishita, T. (2016). Characteristics relating to the seed yield of determinate common buckwheat (Fagopyrum esculentum 'Kitanomashu'). Fagopyrum, 33, 1-5.

Kaschuk, G., Yind, X., Hungriae, M., Leffelaar, P.A., Giller, K.E., Kuyper, T.W. (2012). Photosynthetic adaptation of soybean due to varying effectiveness of $\mathrm{N}_{2}$ fixation by two distinct Bradyrhizobium japonicum strains. Environmental and Experimental Botany, 76, 1-6. https://doi:10.1016/j.envexpbot.2011.10.002

King, R.W., Wardlaw, I.F., Evans, L.T. (1967). Effect of assimilate utilization on photosynthetic rate in wheat. Planta, 77, 261276. https://doi: 10.1007/BF00385296

Kreft, I. (1989). Breeding of determinate buckwheat. Fagopyrum, 9, 57-59.

Long, S.P., Zhu, X.G., Naidu, S.L., Ort, D.R. (2006). Can improvement in photosynthesis increase crop yields? Plant, Cell \& Environment, 29, 315-330. https://doi: 10.1111/j.13653040.2005.01493.x

Luthar, Z., KocjanAčko, D., Kreft, I. (1986). Breeding buckwheat with determinant growth habit. In: Proc. 3rd International Symposium on Buckwheat, part 1 (pp.139-144). Pulawy, Poland.

Marcelis, L.F.M., Heuvelink, E., Baan Hofman-Eijer, L.R., Den Bakker, J., Xue, L.B. (2004). Flower and fruit abortion in sweet pepper in relation to source and sink strength. Journal of Experimental Botany, 55, 2261-2268. https://doi: $10.1093 / \mathrm{jxb} / \mathrm{erh} 245$

Nešković, M., Vinterhalter, B., Miljuš-Djukić, J., Ghalawenji, N. (1990) Micropropagation of recessive determinate genotypes of buckwheat (Fagopyrum esculentum Moench.) as an alternate approach to uniform seed production. https:// doi.org/10.1111/j.1439-0523.1990.tb01294.x

Ohnishi, O. (1990). Analyses of genetic variants in common buckwheat, FagopyrumesculentumMoench: A review. Fagopyrum, 10, 12-22.

Peng, S., Krieg, D.R., Girma, F.S. (1991). Leaf photosynthetic rate is correlated with biomass and grain production in grain sorghum lines. Photosynthesis Research, 28, 1-7. https://doi: 10.1007/BF00027171

Roper, T.R., Williams, L.E. (1989). Net $\mathrm{CO}_{2}$ assimilation and carbohydrate partitioning of grapevine leaves in response to trunk girdling and gibberellic acid application. Plant Physiology, 89, 1136-1140.

Salas-Fernandez, M.G., Strand, K., Hamblin, M.T., Westgate, M., Heaton, E., Kresovich, S. (2015). Genetic analysis and phenotypic characterization of leaf photosynthetic capacity in a sorghum (Sorghum spp.) diversity panel. Genetic Resources and Crop Evolution, 62, 939-950. https://doi:10.1007/ s10722-014-0202-6

Teng, S., Qian, Q., Zeng, D., Kunihiro, Y., Fujimoto, K., Huang, D., Zhu, L. (2004). QTL analysis of leaf photosynthetic rate and related phisiological traits in rice (Oriza sativa L.). Euphytica, 135, 1-7.https://doi:10.1023/B:EUPH.0000009487.89270.e9

Wang, S.G., Jia, S.S., Sun, D.Z., Wang, H.Y., Dong, F.F., Ma, H.X., .Ma, G. (2015). Genetic basis of traits related to stomatal conductance in wheat cultivars in response to drought stress. Photosynthetica, 53, 299-305. https://doi:10.1007/ s11099-015-0114-5

Wang, Y.J., Campbell, C. (2004). Buckwheat production, utilization and research in China. Fagopyrum, 21, 123-133.

Wardlaw, I.F. (1990).The control of carbon partitioning in plants. New Phytologist, 116, 341-381. https:// doi:10.1111/j.1469-8137.1990.tb00524.x

White, A.C., Rogers, A., Rees, M., Osborne, C.P. (2016). How can we make plants grow faster? A source-sink perspective on growth rate. Journal of Experimental Botany, 67, 31-45. https://doi:10.1093/jxb/erv447

Wubs, A.M., Ma, Y., Heuvelink, E., Marcelis, L.F.M. (2009). Genetic differences in fruit-set patterns are determined by differences in fruit sink strength and source: sink threshold for fruit set. Annals of Botany, 104, 957-964. https:// doi:10.1093/aob/mcp181

Yu, H., Murchie, E.H., Gonzalez-Carranza, Z.H., Pyke, K.A., Roberts, J.A. (2015). Decreased photosynthesis in the erect panicle 3 (ep3) mutant of rice is associated with reduced stomatal conductance and attenuated guard cell development. Journal of Experimental Botany, 66, 1543-1552. https://doi:10.1093/jxb/eru525

Zhang, C., Tanabe, K., Tamura, F., Matsumoto, K., Yoshida, A. (2015). ${ }^{13} \mathrm{C}$-photosynthate accumulation in Japanese pear fruit during the period of rapid fruit growth is limited by the sink strength of fruit rather than by the transport capacity of the pedicel. Journal of Experimental Botany, 56, 2713-2719. https://doi:10.1093/jxb/eri264

Zhu, C., Zhu, J., Cao, J., Jiang, Q., Liu, G., Ziska, L.H. (2014). Biochemical and molecular characteristics of leaf photosynthesis and relative seed yield of two contrasting rice cultivars in response to elevated $\left[\mathrm{CO}_{2}\right]$. Journal of Experimental Botany, 65, 6049-6056. https://doi:10.1093/jxb/eru344 